\title{
Implementation of Predict-Observe-Explain (POE) Strategy to Reduce Misconception in Thermochemistry
}

\author{
Imroatuz Zakiyah ${ }^{1, a^{*}}$, Wahono Widodo ${ }^{1, b}$, and Tukiran ${ }^{1, c}$ \\ ${ }^{1}$ Department of Science Education, Post Graduate Program, Universitas Negeri Surabaya, East Java, Indonesia \\ a imroatuzzakiyah@mhs.unesa.ac.id; b wahonowidodo@unesa.ac.id; c tukiran@unesa.ac.id \\ ${ }^{*}$ Corresponding Author \\ Whatsapp number [085692303102]
}

How to Cite : Zakiyah, I., Widodo, W., Tukiran, T. (2019). Implementation of Predict-Observe-Explain (POE) Strategy to Reduce Misconception in Thermochemistry. International Journal for Educational and Vocational Studies, 1 (7), 754-759

\section{ARTICLE HISTORY}

Received: 14 August 2019

Revised: 23 September 2019

Accepted: 26 October 2019

\section{KEYWORDS}

Misconception;

POE Strategy;

Thermochemistry;

\begin{abstract}
This research aims to determine that the implementation of the POE (predict-observe-explain) strategy can be used to correct misconceptions in thermochemistry. This research uses One Group Pretest-Posttest Design. This research was conducted in class XI MIA 5 students at Bhayangkari 3 Porong Senior High School. The sample used was 33 students who were divided into 6 heterogeneous groups. The students are given a conceptual understanding test as pretest and posttest in the form of a three-tier diagnostic test which amounts 20 questions. After pretest the next stage is to do remediation given learning process using worksheet of POE strategy. Then the results of pretest and posttest were then analyzed using Wilcoxon signed rank test. The result is POE (predict-observe-explain) strategy can be used to correct misconceptions in thermochemistry sub-topic for students in class XI of Bhayangkari 3 Porong Senior High School. This is indicated by a decrease in the percentage of students' misconceptions from $66.36 \%$ to $6.36 \%$. In addition, based on the Wilcoxon Sign Rank Test, Asymp. Sig (2-Tailed) has 0 value, it means hypothesis 0 is rejected, which means there is a significant influence on the implementation of learning with POE strategies to improve the student's status of knowing the concept.
\end{abstract}

This is an open access article under the CC-BY-SA license.

\section{INTRODUCTION}

Chemistry learning is a process of interaction between students, teachers, learning resources, and teaching materials in form of chemistry matter in a learning environment in order to achieve learning objectives. This learning process giving learning outcomes result that obtained by students in form of test scores. But based on preliminary studies students assume that chemistry is difficult to learn $(95 \%)$ because there are many concepts that must be understood (70\%).

Based on preliminary study one of the material that considered difficult by students is thermochemistry. $75 \%$ of students think that thermochemistry is difficult because there are many concepts in it. Only 35\% of students can answer the concept questions correctly. This difficulties causes lower in mastery of concepts and give impact in low learning outcome. This can be seen from previous research by Sugiawati (2013) the completeness of the class in thermochemistry material is only $42 \%$ so it still needs to be improved. The low in mastery concepts indicates that the mastery of knowledge competencies is low.

One of the abilities that must possess by student to improve their mastery of knowledge competencies is good understanding of concepts. Concept is a group of stimuli (facts, objects, events) that have same characteristics (attributes) (Ibrahim, 2012). In thermochemistry there are many science concepts that are related to concepts in previous material. But based on the results of Yalçinkaya's research (2009) students stated that thermochemistry is a difficult topic and they have various misconceptions in it.

Misconception is a conception that belongs to someone who is clearly different and often even contrary to scientific concepts (Ibrahim, 2012). Based on research by Inayah (2003) and Rahmayani (2017) found that $31.49 \%$ and $63.72 \%$ of students experienced misconceptions on thermochemistry. Yalçinkaya (2009) in his research found that $30 \%$ of students experienced misconceptions on heat and temperature material; $60 \%$ of students consider all reactions to occur spontaneously as exothermic reactions; $30 \%$ of students think that heat is always needed for 
chemical reactions to occur; students also have misconceptions about bond formation which are believed to be endotherms and bonds dissociation that are exothermic; $45 \%$ of students cannot determine the best fuel by considering changes in enthalpy and the same amount for a combustion reaction, students do not know the system of a reaction; most students cannot determine the system and environment in the calorimeter context; many students do not understand the enthalpy of formation.

According to Saricayir et al., (2016) misunderstanding or lack of understanding of thermochemistry problems is very worrying. There are a number of concepts which judge have the lowest understanding, they are relation between bonding, enthalpy and energy in chemical reactions that might be related to students' inability (or lack of) understanding of breaking and forming of bonds. In line with what was found in the preliminary research that students experienced difficulties when determining the system and environment of a reaction, besides that students also experienced difficulties in determining the exothermic and endothermic reactions, changes in enthalpy of formation and dissociation and Hess's Law.

Misconceptions can prevent students to understand subsequent concepts. Misconceptions that occur must be reduced so that student's understanding and mastery of concepts increase so student can mastery of knowledge competencies that are shown with higher learning outcomes so we need improvement in learning to make student mastery the concept properly and correctly. One way to handle it is through remedial learning programs. According to Tarigan (2009) Remedial teaching is teaching that involves activities of diagnosis, prevention, treatment, healing, and improvement of students' mistakes in learning. Chrisnajanti (2002) states that the learning outcomes after the remedial program are carried out higher so that the program can help students who experience misconceptions, so students' misconceptions in learning material decreased. Handling using remedial learning is expected to be one source of experience for the parties when they wish and determined to improve learning in schools, especially in remediation programs for students' misconceptions (Suyono et al., 2014).

One learning strategy has been used to eliminate misconceptions by using Predict-Observe-Explain (POE) strategy remedial learning. POE is a strategy that was introduced by White and Gunstone in 1992 as an efficient strategy to generate students' ideas in conducting discussions of their ideas (Khantavy, 2009). According to Mursalin (2014) POE learning is better at minimizing student misconceptions than conventional learning models. Besides that Anam (2015) experienced a fairly high decrease in students' misconceptions after learning using the POE strategy. In addition, according to Özdemir (2011) POE strategy provides better teaching of concepts so that they can get a better understanding of concepts and also can reduce concept errors in students. The positive effect of teaching with POE strategies is that students can overcome the misconceptions they experience and improve their learning outcomes (Kibirige et al., 2014).

The Predict-Observe-Explain (POE) strategy has three stages as follows: 1) Predict, the teacher gives the background of the situation then asks students to write down their prediction results and their reasons (why it happens based on students' beliefs); 2) Observe, students make observations, experiments, or learn about how the situation really is; 3) Explain, students try to understand why their predictions are wrong and formulate a new theory to explain what happened (Dalziel, 2010). This strategy will be carried out using the direct instruction model. The direct instruction model can be used as a teacher's guide to assess students' level of knowledge while carrying out group formation activities. Besides that the direct instruction model is effective in improving students' abilities (Slavin, 2011). It would be very interesting if the researchers used POE strategies to reduce misconceptions on thermochemistry. Because all this time research on misconceptions on thermochemistry has been reduced using cognitive conflict and conceptual change strategy. So this study aims to determine that the implementation of the POE (predict-observe-explain) strategy can be used to correct misconceptions in thermochemistry.

\section{METHODS}

This research uses One Group Pretest-Posttest Design. This research was conducted in class XI MIA 5 students at Bhayangkari 3 Porong Senior High School. The sample used was 33 students who were divided into 6 heterogeneous groups. The initial stage students are given a conceptual understanding test (pretest) in the form of a three-tier diagnostic test which amounts 20 questions. Questions number 1-9 about the concept of exotherms and endotherms, questions number 10-13 about changes in enthalpy of formation and dissociation, and questions number 14-20 about Hess's law. This test aims to determine the initial conception of students. The next stage is to do remediation given learning process using worksheet of POE strategy. Furthermore, after learning is finished students are given a second conceptual understanding test (posttest) in the form of a three tier diagnostic test to determine the student's final conception. Then the results were then analyzed using Wilcoxon signed rank test.

\section{RESULTS AND DISCUSSION}

After doing the pretest and posttest obtained data of student's conception who are categorized in 3 types of status namely misconception, don't know the concept and know the concept. The pretest data will be presented in Figure 1 and Table 1. 
Tabel 1. Recapitulation of Student's Conception

\begin{tabular}{|c|c|c|}
\hline Criteria & Pretest (\%) & Posttest (\%) \\
\hline Know the Concept (KC) & 11,36 & 87,58 \\
\hline Don't Know the Concept (DKC) & 22,27 & 6,06 \\
\hline Misconception (MC) & 66,36 & 6,36 \\
\hline
\end{tabular}

Figure 1. Percentage of Student Conception Before and After Implementation of Predict-Observe-Explain Strateg

Based on Figure 1 on the left and Table 1 shows that most students in class XI MIA 5 experience not knowing the concepts and misconceptions on all question. A false initial conception can lead to misconceptions if left unchecked. As Barke et al., (2009), that one of the factors which contributed greatly in inhibiting of satisfying learning achievement, namely the existence of student's misconceptions in chemistry both due to the initial conceptions that were brought when trying to construct the concept itself in his mind. If the misconceptions that occur in students are left it will damage the students' understanding of chemistry because most of the chemistry concepts are interrelated. This initial condition is used to show that students' understanding of the concept o is still small and used as a basis for researchers to conduct Predict-observe-explain learning strategies.

After learning process using POE Strategy, based on Figure 1 on the right and Table 1, it is found that (1) the final conception of students in general changes to know the concept. This is indicated by students who know the concept status overall increased become $87.58 \%$. This means that after learning have done, students' understanding of the concept increases. This is the impact of learning which is to improve and strengthen the concepts of students in construction of knowledge to form new concepts which accordance with scientific concepts (Suparno, 1997), (2) the conception status of students who do not know the concept and misconceptions show a low percentage, this shows that most students have mastered the concept well, (3) some of the status of students' misconceptions cannot be changed to know the concept because students experience resistant misconceptions. This situation is caused by students still fixating on their initial understanding. This condition has been explained by Barke et al., (2009) that misconceptions are resistant or difficult to change and tend to persist. This statement is also supported by Ibrahim (2012) that although students have been introduced to correct concepts but there are still has opportunities to return to their initial conceptions which is wrong (misconception).

Resistance to misconception may occur due to a state disequilibration that is caused by a cognitive conflict process that has not yet reached a state of equilibrium. Equilibration can occur if assimilation and accommodation events occur in an integrated manner (Suyono and Hariyanto, 2011). According to Renner and Lawson (in Effendy, 2002) equilibration results in the development of schemes or structures of student intellect becoming more complex and more useful. Suparno (2013) explains that with assimilation students can adapt new scientific concepts with existing schemes so that the schemes are not overhauled but only expanded, whereas with accommodation students can change existing schemes to be matched with new scientific concepts so that both the process of development cognitive structures can work.

Indicators of successful learning with POE strategy can be seen with an increase in the percentage of students' conception conditions. This means that misconceptions experienced by students decreased. This statement is supported by statements from Anam (2015) and Lebdiana, et al., (2015) which stated by using the POE strategy the misconceptions that occur in student decreased. In addition, according to Kibirige et al., (2014), learning with POE strategies can help in overcoming misconceptions experienced by students because learning using POE strategies can develop the ability to track their initial knowledge and they can find out what is lacking and misconceptions so that they can correct misconceptions or imperfect learning (Özdemir et al., 2011). We can see this in the stages that used in learning process. In this research we have three times learning process. Each meeting in this research was designed by applying the POE strategy in a direct instruction model which means that in direct instruction phases the POE strategy is directly entered. At each meeting there are 2 cycles that repeat. The results of observations of the implementation of POE strategy learning in direct instruction learning model are described as follows:

At the beginning of the activity the teacher gives apperception by conveying concepts that are have relation with the material being taught. At the first meeting the teacher gave apperception by asking the question "who still remembers the meaning of heat?" And "can heat move?". At the second meeting the teacher gave apperception with various kinds of snacks with different calorific values and at the third meeting the teacher gave apperception by reacting $\mathrm{CaO}$ with water and then measuring the temperature. Furthermore, the teacher gives motivation to students, at the first meeting the teacher gives a cold pack to students then students are asked to stick to their hands and describe how they feel. Then at the second meeting the teacher showed a video about high-calorie foods and obesity as the effects of high-calorie foods. At the third meeting the teacher gave a motivational video about metal terminal and the welding process using acetylene gas. Apperception and motivation are given to arouse student interest in learning. Next the teacher conveys the learning objectives to be achieved that are included in phase 1 namely clarifying the objectives and preparing students. In addition teacher also divides students into groups. 
The core activities include in phase 2 namely demonstrating knowledge and skills, in this core activity, the teacher conveys the steps of the POE strategy in the worksheet while demonstrating the steps in completing the worksheet. Worksheet at the 1st meeting cycles 1 is practicum regarding exothermic and endothermic reactions and cycle 2 regarding the characteristics of exothermic and endothermic reactions. Worksheet at 2 nd meeting cycle 1 regarding the characteristics of change in formation enthalpy and cycle 2 regarding the characteristics of change in dissociation enthalpy. Worksheet at 3rd meeting cycle 1 practicum regarding the determination of $\Delta \mathrm{H}$ reaction based on Hess's law and cycle 2 determines the enthalpy change using enthalpy formation data.

Phase 3, namely guiding training in this phase, at this stage two stages of POE strategy are conducted. In the first step Predict, the teacher gives the background of the situation then asks students to write their prediction results and their reasons (why it happens based on students' beliefs) (Dalziel, 2010). In this phase students are given chance to make guesses or predictions with their reasons, the teacher should not limit the students 'thoughts so that many ideas and concepts emerge from students, the teacher will understand how students' concepts and thoughts about the problem being raised. In this prediction process the teacher can also understand a lot of misconceptions which happens to students. This is important for the teacher in helping students to build the correct concepts.

Furthermore, at the second step of Observe, students make observations, experiments or learn about how the situation really is (Dalziel, 2010). Students are invited to make observations from experiments to test the truth of their prediction. Students then observe what happens to experiment then students confirm the prediction which they made earlier. This stage that allows the occurrence of cognitive conflict problems. Cognitive conflict approaches and interesting situations are factors that influence students' conception changes (Kang et al., 2010).

Phase 4 is checking student understanding and giving feedback.In the third step of Explain, students try to understand why their predictions are wrong and formulate a new theory to explain what happened (Dalziel, 2010). Students are also explain the suitability to other students by presenting it in front of the class. If the prediction results are in accordance with the results of observations and after they get an explanation of the truth of the predictions, the students are more confident in the concept. However, if the assumptions are not fixed then students can look for explanations about the inaccuracies in their predictions. Students will experience change in concept from an incorrect concept to a true concept. At this stage students learn from mistakes so they are not easily forgotten. This stage provokes discussion between students and students and between students and teachers. The process that occurs at this stage also develops student reasoning. Students are easier to build understanding if they can communicate their ideas to other students or teachers. Also at this stage helps encourage students to obtain and understand their own knowledge from ideas that students have. During the learning process, the teacher positions as a facilitator and emphasizes the cultivation of correct scientific concepts based on the results of experiments which conducted by students. Activities in this phase are in accordance with the opinion of Ausubel (2003) which explains that, meaningful learning is a process that connects information or knowledge that has been held with new knowledge.

Phase 5 is developing skills and application. In this phase students are asked to examine whether their answers are appropriate or not with the results of previous discussions and students are asked to report their observations. For the closing activity the teacher asks students to reflect on the concepts they get at each meeting and the teacher gives appreciation to the active group.

Learning by using the POE strategy which implemented in this research is accordance with the principles of constructivist learning. The learning tools that developed by researchers come from the profile of misconceptions that experienced by students, students learn concepts in the zone of proximal development. The zone of proximal development is Vygotsky term for a series of tasks that are too difficult for children to master alone but can be learned with the help and guidance of adults or trained children. Assignments during learning through the worksheets help students in working on complex assignments in accordance with misconceptions that they face to support the occurrence of conceptual changes in students. Besides that learning with POE strategies can improve students 'understanding of concepts, this can be found in research conducted by Rosdianto et al., (2017) and Anarky et al., (2016) who find that POE strategies are effective for increasing students' conceptual understanding of Heat and material Temperature. In addition POE strategy is also one technique that allows students to rebuild their understanding without feeling anxious and can be used to evaluate their level of understanding (Kala et al., 2012).

Table 2. Result of Wilcoxon Ranked Sign Test

\begin{tabular}{l|r}
\hline \multicolumn{1}{c}{ Test Statistics ${ }^{\mathrm{b}}$} & \multicolumn{1}{c}{ MCPOSTMIA5 - MCPREMIA5 } \\
\hline$Z$ & \multicolumn{2}{c}{$-3.927^{\mathrm{a}}$} \\
\hline Asymp. Sig. (2-tailed) & .000 \\
\hline a. Based on positive ranks. & \\
\hline b. Wilcoxon Signed Ranks Test &
\end{tabular}


To strengthen the results of the study, Wilcoxon ranked sign test was conducted to show the concept changes that occurred in students as a result of the treatment namely the implementation of the Predict-Observe-Explain (POE) strategy in learning. The confidence level used in this test is $95 \%$. Based on the test results it can be seen that Asymp. Sig (2-Tailed) is 0.000, this value is below 0.05 . The small calculation results indicate that hypothesis 0 is rejected, meaning there is a change in misconception, overall for all students in class XI MIA 5. This means that there is a significant influence on the implementation of learning with POE strategies to improve the student's conceptualized status as result of decreasing misconception status. This statement is supported by research from Kibirige et al, (2014) that POE strategy can have an impact on decreasing students' misconceptions because the POE strategy facilitates to investigate scientific phenomena in small groups, then they make predictions about the phenomenon then observed and then compared predictions and the explanation they make is based on observations that have been made. Students eliminate cognitive conflicts that occur between prediction and observation by explaining so that the POE strategy provides students with a conceptual understanding and deep learning (Şeşen and Mutlu, 2016). So it can be said that the POE strategy facilitates changes in student concepts (Sumirat 2017).

\section{CONCLUSION}

Based on the results of research conducted it can be concluded that the POE (predict-observe-explain) strategy can be used to correct misconceptions in thermochemistry sub-topic for students in class XI of Bhayangkari 3 Porong Senior High School. This is indicated by a decrease in the percentage of students' misconceptions from $66.36 \%$ to $6.36 \%$ in other words students who know the concept increased. In addition, based on the Wilcoxon Sign Rank Test, the Asymp. Sig (2-Tailed) has 0 value, it means hypothesis 0 is rejected, which means there is a significant influence on the implementation of learning with POE strategies to improve the student's status of knowing the concept as the impact of decreasing the students' status of misconceptions.

\section{REFERENCES}

Anam, A. C., \& Edie, S. S. (2015). Penerapan Strategi POE (Predict-Observe-Explain) Untuk Memperbaiki Miskonsepsi Fisika Pada Sub Pokok Bahasan Arus dan Tegangan Listrik Bagi Peserta Didik Kelas X SMA Teuku Umar Semarang. UPEJ Unnes Physics Education Journal, 4(2).

Anarky, V., Syuhendri, S., \& Akhsan, H. (2016, September). The Effectiveness of POE (Predict-Observe-Explain) Based Teaching Strategy in Improving Students' conceptual Understanding. In Sriwijaya University Learning and Education International Conference (Vol. 2, No. 1, pp. 1271-1280).
Ausubel. (2003). Educational Psycology: A Cognitive View. New York: Rinehart and Winston.

Barke, H.D., Al Hazari, and Yitbarek, S. (2009). Misconceptions in Chemistry. Springer Link

Chrisnajanti, W. (2002). Pengaruh Program Remedial Terhadap ketuntasan Belajar Siswa. Jurnal Pendidikan Penabur. No.01/th1/Maret 2002

Dalziel, James. 2010. Practical eTeaching Strategies for Predic-Observe-Explain Problem Based Learning, and Role Plays. Sydney: LAMS International

Effendy. (2002). Upaya untuk Mengatasi Kesalahan Konsep dalam Pengajaran dengan Menggunakan Strategi Konflik Kognitif. Malang: Jurnal Media Komunikasi Kimia. 2(6), 1-19

Ibrahim, Muslimin. 2012. Konsep, Miskonsepsi dan Cara Pembelajarannya. Surabaya: Unesa Press

Inayah, In. 2003. Studi Miskonsepsi Pembelajaran Kimia Siswa Kelas II Semester Gasal MAN Yogyakarta 1 Tahun Ajaran 2002/2003. Downloaded digilib.uin-suka.ac.id/9487/2/BAB\%20I.\%20V.pdf at November $15^{\text {th }} 2019$

Kala, Nesli et al., (2013). The Effectiveness of Predict-Observe-Explain Technique in Probing Student's Understanding about Acid-Base Chemistry: A Case for the Concept of $\mathrm{PH}, \mathrm{POH}$ and Strength. International Journal of Science and Mathematics Education Vol. 11. 555-574

Kang, H., Scharmann, L. C., Kang, S., \& Noh, T. (2010). Cognitive conflict and situational interest as factors influencing conceptual change. International journal of environmental and science education, 5(4), 383-405.

Khathanvy, H., \& Yuenyong, C. (2009). The Grade Student's Mental Model of Force and Motion through Predict-Observe-Explain (POE) Strategy. Thailand: Khon Kaen University.

Kibirige, I., Osodo, J., \& Tlala, K. M. (2014). The Effect of Predict-Observe-Explain Strategy on Learners' Misconceptions about Dissolved Salts. Mediterranean Journal of Social Sciences, 5(4), 300.

Lebdiana. R, Sulhadi, \& Hindarto, N. (2015). Pengembangan Perangkat Pembelajaran Materi Suhu Dan Kalor Berbasis POE (Predict-Observe-Explain) Untuk Meremediasi Miskonsepsi Siswa. Unnes Physics Education Journal. 4(2)

Mursalin. (2014). Meminimalkan Miskonsepsi Pada Materi Rangkaian Listrik Dengan Pembelajaran Predict-Observe-Explain. Jurnal Ilmu Pendidikan. 20. 1

Özdemir, Hakan, dkk. (2011). Effect of Laboratory Activities Designed Based on Prediction- Observation Explanation (POE) Strategy On Pre-Service Science Teachers' Understanding Of Acid base Subject. Western Anatolia Journal of Educational Sciences (WAJES)

Rahmayani, R. F. I. (2017). Identifikasi Kesulitan Siswa dalam Memahami Materi Termokimia dengan Menggunakan Three-Tier Multiple Choice Diagnostic 
Instrument di Kelas XI MIA 5 MAN MODEL Banda Aceh. Jurnal Ilmiah Mahasiswa Pendidikan Kimia, 2(1).

Rosdianto, Haris, Murdani, Eka, Hendra. (2017). Implementasi Model Pembelajaran POE (Predict Observe Explain) Untuk Meningkatkan Pemahaman Konsep Siswa Pada Materi Hukum Newton. Jurnal Pendidikan Fisika. Vol.6. No.1

Saricayir, Hakan et al., (2016). Determining Students' Conceptual Understanding Level of Thermodynamics. Journal of Education and Training Studies. Vol 4. 6.

Şeşen, Acar and Mutlu, Ayfer. (2016). Predict-Observe-Explain Tasks in Chemistry Laboratory: Pre-Service Elementary Teachers' Understanding and Attitudes. Sakarya University Journal of Education. 6/2

Slavin, R. 2011. Psikologi Pendidikan Teori dan Praktik. Jakarta: Indeks

Sugiawati, Vinsenia Ade. (2013). Penggunaan Strategi Konflik Kognitif Dalam Pembelajaran TPS Untuk Mereduksi Miskonsepsi Siswa Pada Materi Termokimia. Jurnal Nalar Pendidikan. Vol.1

Sumirat, Fanny. (2017). Efektivitas Model Pembelajaran Predict Observe Explain (POE) Untuk Memfasilitasi Perubahan Konseptual Siswa SD dalam Pembelajaran IPA. Tunas Siliwangi. Vol 3. 75-85

Suparno, Paul. (1997). Filsafat Konstruktivisme dalam Pendidikan. Yogyakarta: Kanisius

Suparno, Paul. (2013). Miskonsepsi \& Perubahan Konsep dalam Pendidikan Fisika. Jakarta: Grasindo

Suyono dan Hariyanto. (2011). Belajar dan Pembelajaran Teori dan Konsep Dasar. Bandung: Rosda.

Suyono, Amaria, Muchlis, dan Setiarso, P. (2014). Diseminasi Model Prevensi dan Kurasi Miskonsepsi Siswa pada Konsep Kimia. Laporan Akhir Penelitian Unggulan Perguruan Tinggi. Surabaya: LPPM Unesa

Tarigan, Henry Guntur. (2009). Pembelajaran Remedi Bahasa. Bandung: Angkasa

Yalçınkaya, E., Taştan, Ö.,\& Boz, Y. (2009). High School Students' Conceptions about Energy in Chemical Reactions. Pamukkale University Journal of Education, 26, $1-11$. 